\title{
Food chain structure of the North Sea plankton communities: seasonal variations of the role of the microbial loop
}

\author{
Torkel Gissel Nielsen ${ }^{1}$, Katherine Richardson ${ }^{2}$
}

${ }^{1}$ Marine Biological Laboratory, University of Copenhagen, Strandpromenaden 5, DK-3000 Helsingør, Denmark
${ }^{2}$ Danish Institute for Fisheries and Marine Research, Charlottenlund Castle, DK-2920 Charlottenlund, Denmark

\begin{abstract}
Carbon flow in the plankton community was examined in various regions of the North Sea from 24 February to 4 March 1988. At this time, the spring phytoplankton bloom had begun in southern but not in northern regions. Bacterial abundance and production were highest in the Dogger Bank region where the spring bloom was under development, but there was no evidence of substantial carbon flow through the 'microbial loop' at this or any other station sampled. However, comparisons between ratios of bacterial carbon to phytoplankton carbon obtained on this and a subsequent (May/June) cruise, show that the 'microbial loop' contributes substantially to carbon cycling during summer. During the February/March cruise, copepod production rates were substantially higher in the southern than in the northern North Sea. For all stations it was estimated that $<5 \%$ of total daily primary production was grazed by the copepod community. The bulk of the primary production occurring in the North Sea at this time of the year is, therefore, transferred directly to the benthos.
\end{abstract}

\section{INTRODUCTION}

During the last decade, the ecological roles of planktonic bacteria and protozooplankton have received much attention and a number of studies (Hobbie et al. 1977, Fuhrman \& Azam 1980) have demonstrated that the role of bacterioplankton in aquatic ecosystems must be re-evaluated. It has been estimated that 10 to $50 \%$ of the carbon fixed by primary producers is released as dissolved organic carbon (DOC) (Larsson \& Hagström 1982). Such material is rapidly taken up by bacterioplankton and this, together with observations of coupled prey-predator oscillations between estuarine bacteria and heterotrophic nanoflagellates (Fenchel 1982), resulted in the postulation of the 'microbial loop' (Azam et al. 1983). This loop returns 'lost' energy (dissolved organic carbon, DOC) via bacterio- and protozooplankton to the main food chain and thus retains some of the potential energy of dissolved organics for the benefit of zooplankton

Our understanding of the quantitative role of the 'microbial loop' is primarily based on work with batch cultures (Andersen \& Fenchel 1985) or on studies of estuarine environments (Andersen \& Sørensen 1986, Bjørnsen et al. 1988). A coupling between the 'micro- bial loop' and the 'traditional food chain' has been established in estuarine environments (reviewed by Sherr et al. 1986). Less research on the 'microbial loop' has been conducted in open marine waters (Sorokin 1977, Sieburth \& Davis 1982, Andersen 1988).

Other aspects of plankton food chains in the open sea are better understood. Phytoplankton blooms, for example, mainly occur at spatio-temporal transitions from unstable to stable conditions (Legendre et ai. 1986). A well-known response to such a temporal transition is the spring phytoplankton bloom, where phytoplankton production responds to the more favorable light conditions resulting from a vernal reduction in the depth of the surface mixed layer (increase in water column stability and in solar radiation).

In most temperate seas, one (or more) distinct phytoplankton bloom(s) occurs in surface waters during the year. In temperate waters, a spring diatom bloom is normally followed by late summer and/or autumn blooms of dinoflagellates (Cushing 1959). The fate of the production occurring in these blooms is important since it constitutes a large part of the annual primary production (Evans \& Parslow 1985). Studies in coastal waters (e.g. Dagg et al. 1982, Nicolajsen et al. 1983) show that only about $10 \%$ of the primary production of 
the spring bloom is consumed by copepods and the major part of the spring bloom is transferred directly to the benthos. Whether or not this is the rule for oceanic waters has been given little consideration (Smetacek 1984).

Steele (1974) argued that most of the primary production of the North Sea is grazed by copepods and that organic material which reaches the bottom is mainly in the form of sinking faecal pellets. A budget for the carbon cycling of the Belgian coastal zone, however, revealed that only ca $20 \%$ of annual net primary production is grazed by zooplankton (Joris et al. 1982). In the central North Sea, copepod grazing has been shown to correspond to 14,9 and $3 \%$ of the primary production during the months of May, June and September, respectively (Baars \& Fransz 1984). A study of population dynamics and production of Calanus finmarchius on Fladen Ground in the northern North Sea, however, suggests that this copepod is responsible for the depletion of the phytoplankton standing stock resulting from the spring bloom (Williams \& Lindley 1980). A long-term study of copepod production off the Northumberland coast in the North Sea (Roff et al. 1988) indicated that the spring bloom is 'missed' by the copepods, but that it is, to some degree, grazed by protists which later may become an alternative food source for copepods.

Thus, despite the large number of plankton studies carried out in various regions of the North Sea, a synthesis of carbon flow dynamics and especially one including the microbial loop is still lacking.

This study was carried out in the open North Sea in late winter/early spring during a period when the spring bloom had begun in the southern regions but had not yet developed in the north. The purpose of the study is to describe and compare the carbon flow through the 'microbial loop' and the 'traditional food chain' within and between the 2 regions.

\section{MATERIALS AND METHODS}

All data used in this study were collected on cruises with the RV 'Dana' (Danish Fisheries Ministry). The main cruise was from 24 February to 4 March 1988. Data obtained on a cruise from 27 May to 14 June 1988 are also employed.

February/March cruise. In all, 28 stations were visited during the February/March cruise (Fig. 1). However, Stns 5 to 15 and 19 to 26 were carried out at the same geographic positions at different times. Thus, a total of 10 localities were visited. Weather conditions were extremely harsh (winds of up to $30 \mathrm{~m} \mathrm{~s}^{-1}$ and occasionally more were recorded) and strong currents were reported during some periods. Although the geo-

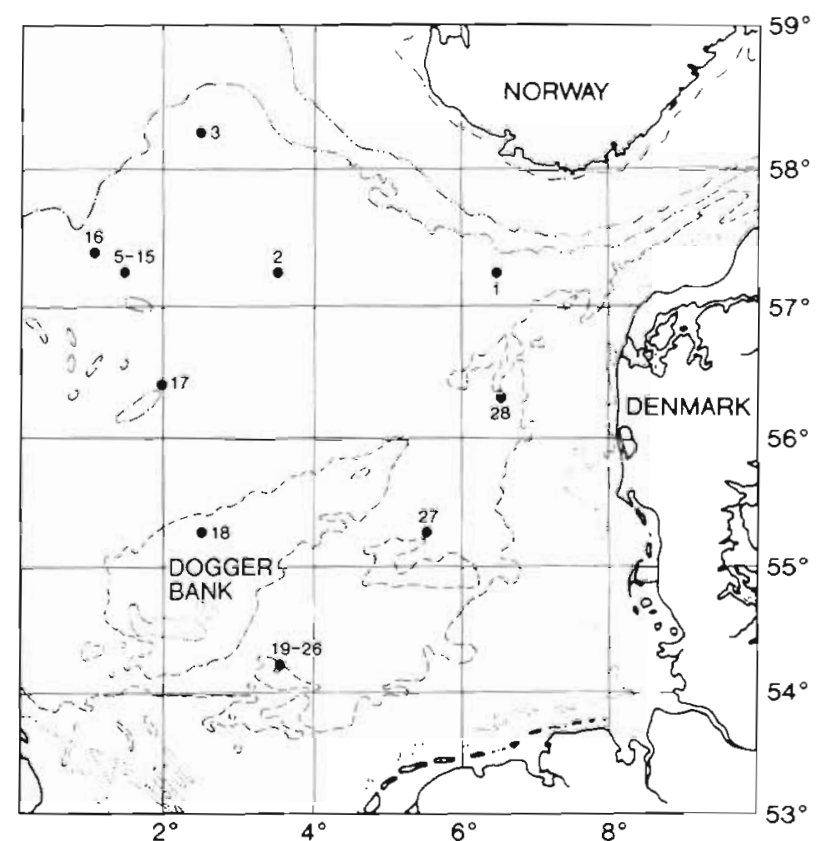

Fig. 1. The North Sea, showing positions of stations investigated during the February/March cruise. Depth contours: (….) $20 \mathrm{~m}$; (---) $40 \mathrm{~m}$; (-.-.) $10 \mathrm{~m}$; (-.-) $200 \mathrm{~m}$

graphic position of some stations remained essentially unchanged, different water masses were sampled during each sampling and we therefore treated the data set as consisting of 28 different stations.

May/June cruise. During the cruise conducted from 24 May to 14 June, water samples were taken in the northern part of the area sampled in February/March (Fig. 7). Samples were taken at a depth of $20 \mathrm{~m}$ and treated as described for the February/March cruise.

Sampling. At all stations, we measured temperature, salinity and chlorophyll a concentrations throughout the water column and primary production at $20 \mathrm{~m}$. Secondary production estimates (copepod egg production) were carried out at selected stations over the entire study area. Additional primary production determinations were carried out along with bacterial and protozooplankton studies at Stns 6, 13, 16, 18, 19, 24 and 27

Temperature and salinity were recorded using a Neil Brown CTD. Samples for calibration of the salinity probe were taken at varying depths at randomly selected stations. Chlorophyll a fluorescence was measured with a $Q$ Instruments fluorometer Calibration of the fluorometer was made by making spectrophotometric determination (Lorenzen method) of chlorophyll in extracts ( $90 \%$ acetone) from 3 depths at selected stations. A carbon/chlorophyll a conversion factor of 50 was used in estimating the phytoplankton biomass. This is within the range (39 to 87) measured by Richardson et al. (1986) during September in the 
North Sea and in agreement with earlier carbon/ chlorophyll determinations from other regions (e.g. Antia et al. 1963). Nutrient concentrations were determined according to Grashoff (1976).

In connection with the bacteria/protozooplankton studies, samples for primary production were taken at 3,20 and (if possible) $60 \mathrm{~m}$. Samples for productivity determinations were kept in subdued light, and transferred to $25 \mathrm{ml}$ acid-washed Pyrex bottles. Four $\mu \mathrm{Ci}$ of a $\mathrm{NaH}^{14} \mathrm{CO}_{3}$ solution were added to each bottle. The ${ }^{14} \mathrm{C}$ addition was checked by taking $50 \mu$ l subsamples of the incubation media and adding them to $500 \mu \mathrm{l} \beta$-phenylethylamine. These were stored for later counting. Samples were attached to a rotating wheel and incubated for $2 \mathrm{~h}$ at ambient seawater temperature $\pm 2{ }^{\circ} \mathrm{C}$. For all depths incorporation of ${ }^{14} \mathrm{C}$ was measured at 7 photon flux densities from 0 to $320 \mu \mathrm{mol} \mathrm{m} \mathrm{m}^{-2} \mathrm{~s}^{-1}$. On routine stations, ${ }^{14} \mathrm{C}$ incorporation in the particulate fraction $(>0.22 \mu \mathrm{m})$ was determined. For measurements made in conjunction with bacterial activity determinations, ${ }^{14} \mathrm{C}$ incorporation was determined in 3 fractions: $>3 \mu \mathrm{m}, 0.22-3 \mu \mathrm{m}$ and $<0.22 \mu \mathrm{m}$ (DOC). To determine ${ }^{14} \mathrm{C}$ associated with DOC, $2 \mathrm{ml}$ of $0.22 \mu \mathrm{m}$ filtrate were placed in scintillation vials to which $0.5 \mathrm{ml}$ of $1 \mathrm{~N} \mathrm{HCl}$ had previously been added. Samples were air bubbled ( $30 \mathrm{~min})$ and counted in Instagel. For both particulate and DOC production, the values obtained from the dark incubations were subtracted from the values obtained in light incubations. Procedures and calculations used for both chlorophyll and particulate primary production determinations are fully described in Richardson (1985).

Phytoplankton samples were collected from $3 \mathrm{~m}$ at selected stations using water bottles and about $500 \mathrm{ml}$ were preserved in Lugols iodine. In the laboratory samples were concentrated $(\times 100)$ by sedimentation and examined with an inverted microscope. The first 150 cells encountered were identified in order to qualitatively describe the phytoplankton community.

Bacterial numbers were quantified in 4 replicates from each sample using the acridine orange technique (Hobbie et al. 1977) with an Olympus BH-2 epifluorescence microscope equipped with a mercury light source, under $1250 \times$ magnification.

Samples were preserved by the addition of buffered formalin ( $1 \%$ final concentration). Subsamples of $10 \mathrm{ml}$ (February/March) or $1 \mathrm{ml}$ (May/June) were stained with acridine orange for $5 \mathrm{~min}$, filtered onto $0.2 \mu \mathrm{m}$ black Nuclepore filters, and the dry filters mounted in paraffin oil. At least 400 bacteria were counted on each filter. Bacterial volume was calculated from length and width measurements (to the nearest $0.3 \mu \mathrm{m}$ ) of at least 50 cells per filter. The mean cell volume per filter was calculated. The biovolume per sample was calculated by multiplication of the cell number by mean volume. A conversion factor of $0.12 \mathrm{pg} \mathrm{C} \mathrm{mm}^{-3}$ (Watson et al. 1977) was used to calculate the carbon biomass.

We estimated bacterial production with the ${ }^{3} \mathrm{H}$-thymidine technique (Fuhrmann \& Azam 1980). Immediately following sampling, 2 or 3 replicates $(20 \mathrm{ml}$ ) from each depth were incubated with $10 \mathrm{n} M$ methyl $-{ }^{3} \mathrm{H}$ thymidine ( $20 \mu \mathrm{Ci} \mathrm{nmol}{ }^{-1}$. New England Nuclear) for $30 \mathrm{~min}$ at in situ temperature $\left( \pm 2^{\circ} \mathrm{C}\right)$. Incubations were stopped by the addition of buffered formalin ( $1 \%$ final concentration) and filtered onto $0.2 \mu \mathrm{m}$ cellulose nitrate filters. The filters were washed 10 times with $5 \%$ ice-cold TCA and counted by liquid scintillation counting. Blanks were prepared by addition of formalin prior to the addition of ${ }^{3} \mathrm{H}$-thymidine.

Incorporated ${ }^{3} \mathrm{H}$-thymidine was converted to cell production with a conversion factor of $1.1 \times 10^{18}$ cells $\mathrm{mol}^{-1}$ thymidine incorporated (Riemann et al. 1987). Bacterial substrate consumption was estimated from the measured net production and assuming a growth yield of $50 \%$ (Cole 1982).

The abundance of the heterotrophic nanoflagellates was determined by epifluorescence microscopy according to Andersen \& Sørensen (1986). The diameter of the roughly spherical cells was measured on about 50 flagellates per station. Biovolume was calculated assuming spherical form and converted to biomass by multiplication by $0.12 \mathrm{pg} \mathrm{C} \mathrm{mm}^{-3}$ (Fenchel 1982). Clearance was estimated as the mean cell volume $\times 10^{5} \mathrm{~h}^{-1}$ (Fenchel 1986).

Depth-integrated zooplankton samples were collected using a submersible pump (3000 l $\left.\mathrm{min}^{-1}\right)$ lowered through the water column at $10 \mathrm{~m} \mathrm{~min}^{-1}$. Samples were successively filtered through 200, 100 and $30 \mu \mathrm{m}$ mesh sieves and the retained fractions preserved in $2 \%$ buffered formalin. Zooplankters in subsamples $(1 / 100$ to $1 / 1000$ ) were later counted and identified and, in the case of copepods, staged and sexed (i.e. egg, NI to III, NIV to VI, CI to III, CIV to V and adult female or male). Abundance data for copepods were converted into biomass with length/weight regressions taken from the literature (Table 1) and a conversion factor from dry weight to carbon of $45 \%$ (Kiørboe et al. 1985b). Samples of $1 \mathrm{l}$ were preserved in Lugols iodine and the microzooplankton identified using an inverted microscope and a settling chamber.

Copepod egg production was determined according to Kiørboe et al. (1985a). Adult females were sampled in the mixed layer using a WP-2 opening-closing net. Immediately after collection, fertilized females were sorted and placed in 600 or $1130 \mathrm{ml}$ bottles (Millipore with 1 to 5 individuals in each) containing surface water. The bottles ( 4 to 6 per species) were incubated for 22 to $24 \mathrm{~h}$ on a rotating wheel $(0.5 \mathrm{rpm})$ at in situ temperature $\left( \pm 2 \mathrm{C}^{\circ}\right)$. At the end of the experiment, spawned eggs were counted. Berggreen et al. (1988) 

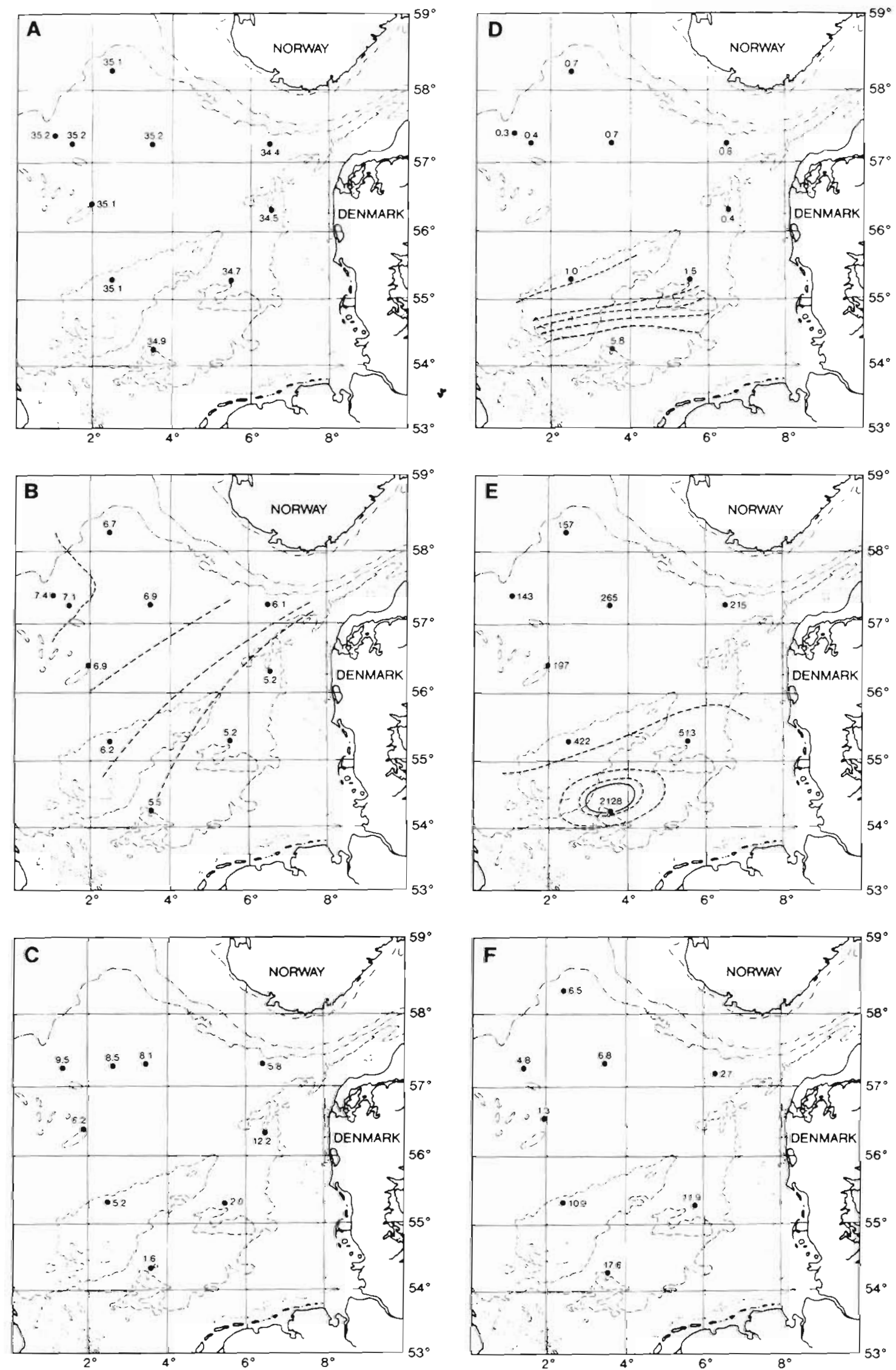

Fig. 2. Distribution of physical, chemical and biological parameters recorded during the February/March cruise. (A) Salinity $(\%$ of

(B) Temperature $\left({ }^{\circ} \mathrm{C}\right)$. (C) $\mathrm{NO}_{3}-\mathrm{N}\left(\mu \mathrm{g}\right.$-at. $\left.\mathrm{l}^{-1}\right)$. (D) Chlorophyll a $\left(\mu \mathrm{g} \mathrm{l} \mathrm{l}^{-1}\right)$. (E) Primary production $\left(\mathrm{mg} \mathrm{C}^{-2} \mathrm{~d}^{-1}\right)$. (F) Calanus finmarchius egg production rate (egg female ${ }^{1} \mathrm{~d}^{-1}$ ) 
Table 1. Literature used in the conversion of copepod abundance to biomass

\begin{tabular}{|c|c|c|}
\hline Species and stage & & Source \\
\hline Acartia spp. & (all stages) & Berggreen et al. (1988) \\
\hline Centropages typicus & (all stages) & Klein Breteler et al. (1982) \\
\hline Pseudocalanus spp. & (all stages) & Klein Breteler et al. (1982) \\
\hline Temora longicornis & (all stages) & Klein Breteler et al. (1982) \\
\hline Calanus spp. & (copepodites and adults) & Bottrell \& Robins (1984) \\
\hline Calanus spp. & (nauplii) & as Acartia \\
\hline Paracalanus parvus & (copepodites and adults) & Cohen \& Lough (1981) \\
\hline Paracalanus parvus & (nauplii) & as Pseudocalanus \\
\hline Metridia lucens & & as Calanus \\
\hline Microcalanus sp. & & as Acartia \\
\hline Oithona spp. & & as Acartia \\
\hline
\end{tabular}

showed that juvenile growth rate and female specific egg production rate were equal for Acartia tonsa. Therefore, the egg production rate can be used for estimating the production of the entire copepod population, assuming equal food availability for all stages. The copepod consumption rate was calculated from the egg production rate, assuming a gross efficiency of $33 \%$ (this value is nearly constant among different copepod species; see Peterson 1988).

\section{RESULTS}

\section{February/March cruise}

The temperature and salinity profiles revealed vertical homogeneity at all stations. This was due to the severe weather conditions at the time of sampling, and even at the northerly stations, where depths exceeded $100 \mathrm{~m}$, sand grains occurred in large numbers in the phytoplankton samples taken at $3 \mathrm{~m}$. Marked horizontal temperature and salinity gradients were, however, observed with temperatures ranging from $7^{\circ} \mathrm{C}$ at the deep northwesterly stations to ca $5^{\circ} \mathrm{C}$ at the more shallow southeasterly stations (Fig. 2A, B).

The lowest concentrations of $\mathrm{NO}_{3}-\mathrm{N}$ (surface) were in general observed at Stns 19 to 26 (just south of the Dogger Bank) where the greatest phytoplankton activity was recorded; the highest concentrations of $\mathrm{NO}_{3}-\mathrm{N}$ were observed at Stn 28 (the Jutland coastal station) (Fig. 2C). Chlorophyll concentrations (Fig. 2D) also showed a north-south trend with the lowest values $\left(<0.5 \mu \mathrm{g} \mathrm{l}^{-1}\right)$ being recorded at the most northwesterly stations. Values $>1 \mu \mathrm{g} \mathrm{l}^{-1}$ were only observed in the relatively shallow waters south of $56^{\circ} \mathrm{N}$. In general, the highest chlorophyll concentrations were observed on or near the Dogger Bank. The highest chlorophyll value recorded in the study was $7.3 \mathrm{\mu g} \mathrm{l}^{-1}$, at Stn 19 (at a depth of $12 \mathrm{~m}$ ).

Primary production estimates paralleled the increase in chlorophyll concentrations from north to south. At the northermost stations primary production was estimated to be from 100 to $250 \mathrm{mg} \mathrm{C} \mathrm{m}^{-2} \mathrm{~d}^{-1}$, while south of $56^{\circ} \mathrm{N}$, estimates were from 400 to $2000 \mathrm{mg} \mathrm{C} \mathrm{m}^{-2} \mathrm{~d}^{-1}$ (Fig. 2E). The fractionated primary production is shown in Fig. 3C; the major part of the production was due to the size fraction larger than $3 \mu \mathrm{m}$. The relative importance of this fraction increased at the Dogger Bank as compared with the northern stations.
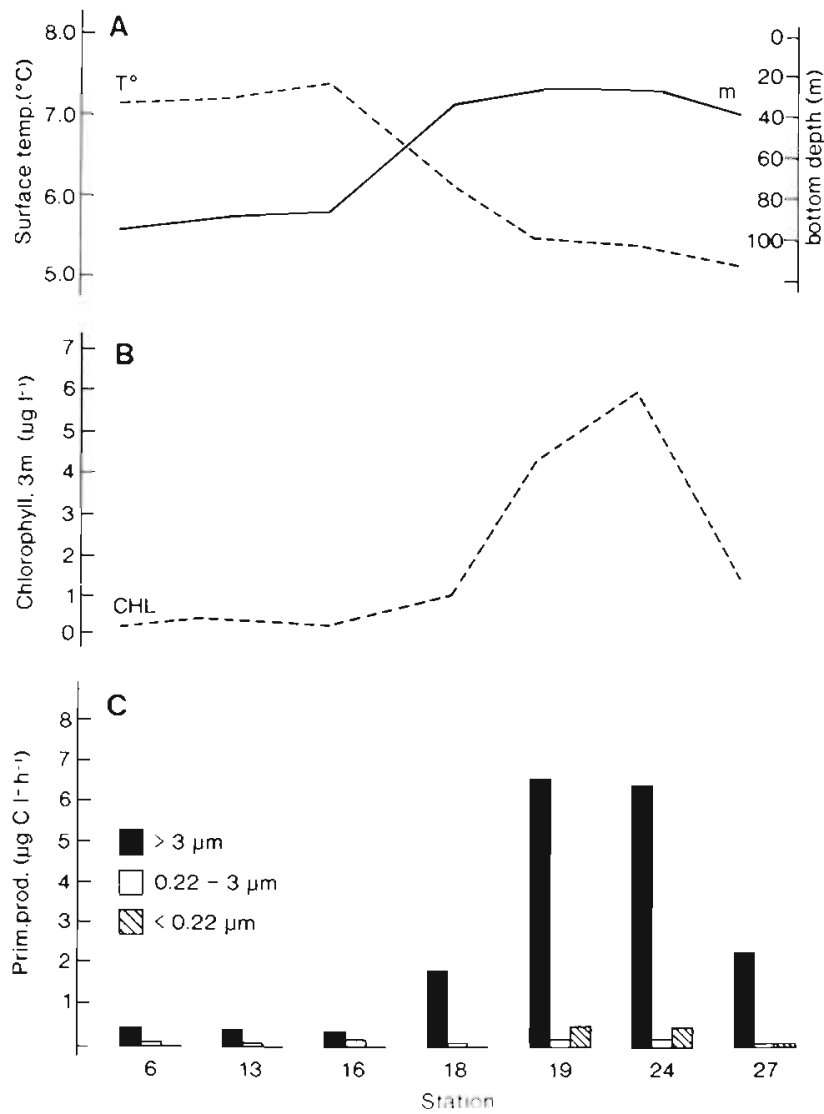

Fig. 3. A transect from the northern to the southern North Sea during the February/March cruise. (A) Temperature $\left({ }^{\circ} \mathrm{C}\right)$ and depth $(\mathrm{m}) ;(\mathrm{B})$ chlorophyll $\left(\mu \mathrm{g} \mathrm{1}^{-1}\right) ;(\mathrm{C})$ fractionated primary production ( $\mu \mathrm{g} \mathrm{C} 1^{-1} \mathrm{~h}^{-1}$ ) 
Table 2. Bacterial volume $\left(\mu \mathrm{m}^{3}\right)$ measured during the February/March cruise

\begin{tabular}{rccccccc}
\hline Depth & \multicolumn{7}{c}{ Station } \\
& 6 & 13 & 16 & 18 & 19 & 24 & 27 \\
\hline $3 \mathrm{~m}$ & 0.124 & 0.147 & 0.175 & 0.149 & 0.091 & 0.164 & 0.123 \\
$20 \mathrm{~m}$ & 0.125 & 0.125 & 0.137 & 0.198 & 0.106 & 0.139 & 0.129 \\
$60 \mathrm{~m}$ & 0.058 & 0.120 & 0.077 & & & & \\
\hline
\end{tabular}

The phytoplankton population was dominated by diatoms at all stations. However, there were marked differences between the different regions. At Stns 6 and 13 , the dominant species ( $\geqslant 10 \%$ of the identified cells) were Nitzschia longissima, Plagiogramma brockmanni, Detonula confervacea and small pennate diatoms. At the northern boundary of the Dogger Bank (Stn 18) the phytoplankton was dominated by Chaetoceros decipiens (30\%), Melosira sulcata (22\%) and Rhizoselenia shrubsolei (10\%). Stn 19 was dominated by $R$. shrubsolei (20\%), Rhizoselenia stolterfothii $(10 \%), D$. confervacea $(10 \%)$ and $P$. brockmanni $(31 \%) . R$. shrubsolei and $R$. stolterfothii dominated the population of $\operatorname{Stn} 24$ with 32 and $16 \%$ respectively. Stn 27 , again, was dominated by $R$. shrubsolei ( $46 \%$ ). However, more than $25 \%$ of the Rhizoselenia cells counted consisted only of empty frustules $11 \%$ of the total number of phytoplankton cells counted) suggesting that the Rhizoselenia bloom at this station was in decline. The other dominant species at $\operatorname{Stn} 27$ was $P$. brockmanni $(11 \%)$.

Bacterial biomass and activity (Fig. 4) roughly followed the trends outlined by the chlorophyll $a$ and primary productivity (Figs. $3 \mathrm{~B}, \mathrm{C}$ ) although the ratio of bacterial biomass: chlorophyll a was much higher north of $56^{\circ} \mathrm{N}$ than at the southern stations. A mean of $57 \%$ of the counted cells were rod shaped. There were no significant differences among the size distributions of the bacterioplankton between depths or stations. Table 2 shows average bacterial volume. Bacterial abundance at $3 \mathrm{~m}$ depth (Fig. 4) was about $1 \times 10^{8}$ cells $^{-1}$ at the northern stations $(6,13,16$ and 18$)$ and peaked at about $3 \times 10^{8}$ cells $1^{-1}$ in the shallow water of Stn 19 . Abundance was about $2 \times 10^{8}$ cells $1^{-1}$ at Stns 24 and 27 (Fig. 4). Bacterial biomass revealed the same trends as abundance. Bacterial production ranged from about $0.2 \mu \mathrm{g} \mathrm{Cl}^{-1} \mathrm{~d}^{-1}$ (Stn 6) to a peak of ca $2.7 \mu \mathrm{g} \mathrm{Cl}^{-1} \mathrm{~d}^{-1}$ at Stn 19 to about $0.4 \mu \mathrm{gC} \mathrm{I}^{-1} \mathrm{~d}^{-1}$ at Stn 27 (Fig. 4). Biomass and production of the bacterioplankton were roughly identical at 3 and $20 \mathrm{~m}$ while they were much lower at $50 \mathrm{~m}$ depth (Fig. 4 ).

Table 3 shows the abundance, biomass and calculated clearance of the heterotrophic nanoflagellates. Mean diameter of the nanoflagellates was $3.5 \mu \mathrm{m}$ corresponding to a cell volume of $23 \mu^{3}$. There were about $0.5 \times 10^{5}$ cells $l^{-1}$ at Stns 6 to 18 , increasing to $1 \times$
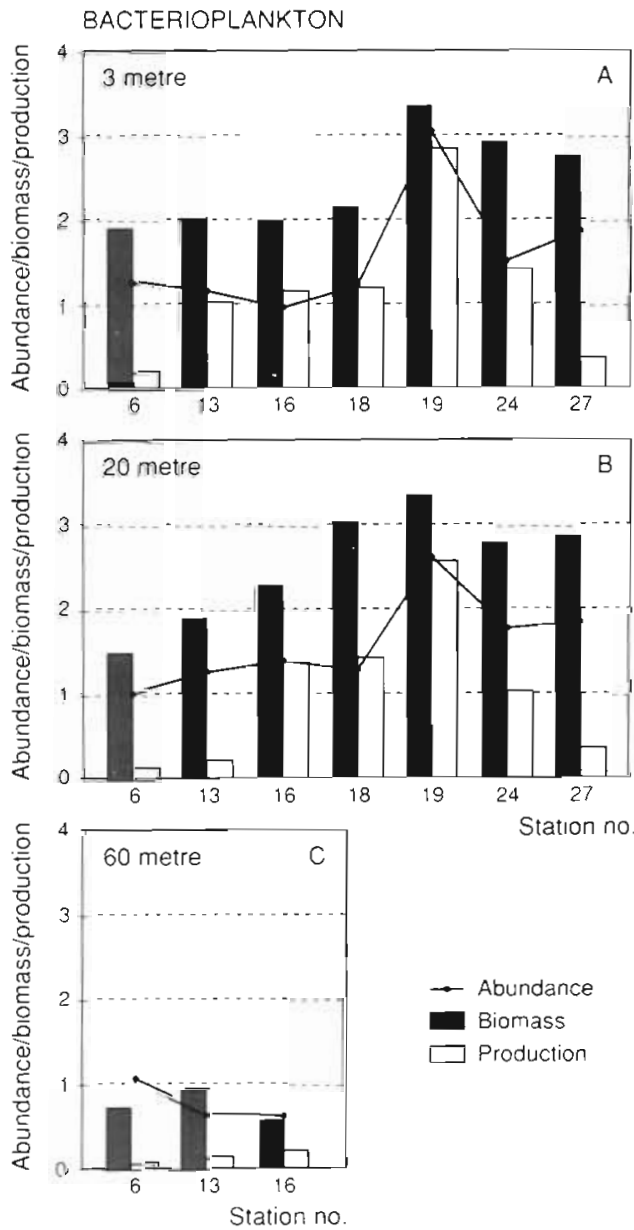

Station no

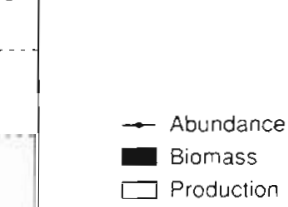

Fig. 4. Bacterioplankton abundance $\left(\times 10^{8} 1^{-1}\right)$, biomass

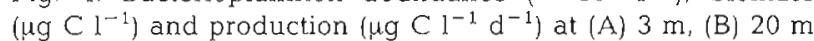
and (C) $60 \mathrm{~m}$ depth during the February/March cruise

$10^{5}$ cells $1^{-1}$ just south of the Dogger Bank (Stns 19 and 24) and about $0.5 \times 10^{5}$ cells $^{-1}$ at $\operatorname{Stn} 27$. The biomass was $0.1,0.3$ and $0.1 \mu \mathrm{g} \mathrm{CI^{-1 }}$ at Stns 6 to 18,19 and 24 , and 27 , respectively. The calculated clearance was low: 0.1 to $0.3 \%$ of the water column per day at the northwesterly stations, 0.5 to $0.6 \%$ on the Bank and $0.2 \%$ at Stn 27.

Copepods dominated the zooplankton (>30 $\mu \mathrm{m})$. A total of 10 genera or species were identified in the samples. Four taxa - Calanus spp., Metridia lucens, Oithona spp. and Paracalanus parvus - dominated the 
Table 3. Number, biomass and calculated clearance of heterotrophic nanoflagellates during the February/March cruise

\begin{tabular}{|c|c|c|c|c|c|c|c|}
\hline \multirow[t]{2}{*}{ Depth } & \multicolumn{7}{|c|}{ Station } \\
\hline & 6 & 13 & 16 & 18 & 19 & 24 & 27 \\
\hline & \multicolumn{7}{|c|}{ Abundance $\left(\times 10^{3} l^{-1}\right)$} \\
\hline $3 \mathrm{~m}$ & 55 & 35 & 20 & 28 & 95 & 100 & 38 \\
\hline $20 \mathrm{~m}$ & 40 & 40 & 25 & 35 & 105 & 85 & 32 \\
\hline \multirow[t]{2}{*}{$60 \mathrm{~m}$} & 60 & 20 & 20 & & & & \\
\hline & \multicolumn{7}{|c|}{ Biomass $\left(\mu \mathrm{g} \mathrm{C} \mathbf{l}^{-1}\right.$ ) } \\
\hline $3 \mathrm{~m}$ & 0.15 & 0.10 & 0.06 & 0.08 & 0.26 & 0.27 & 0.10 \\
\hline $20 \mathrm{~m}$ & 0.11 & 0.11 & 0.07 & 0.10 & 0.29 & 0.23 & 0.09 \\
\hline \multirow[t]{2}{*}{$60 \mathrm{~m}$} & 0.17 & 0.06 & 0.06 & & & & \\
\hline & \multicolumn{7}{|c|}{ Clearance $\left(\%\right.$ of water column $\left.\mathrm{d}^{-1}\right)$} \\
\hline $3 \mathrm{~m}$ & 0.30 & 0.19 & 0.11 & 0.16 & 0.52 & 0.55 & 0.21 \\
\hline $20 \mathrm{~m}$ & 0.22 & 0.22 & 0.14 & 0.19 & 0.60 & 0.47 & 0.18 \\
\hline $60 \mathrm{~m}$ & 0.33 & 0.11 & 0.11 & & & & \\
\hline
\end{tabular}

community, except at Stns 21 and 27 where the neritic species Centropages typicus and Temora longicornis appeared in significant numbers.

Fig. 5 shows the abundance of copepod eggs, nauplii, copepodites and adults at a selection of stations. The distribution of copepod eggs reflects the increase in chlorophyll and primary production from north to south, with the lowest numbers at the deep northern stations (1 to 17) and a peak in the shallow and productive Dogger Bank region (Fig. 5A). Similar distribu-
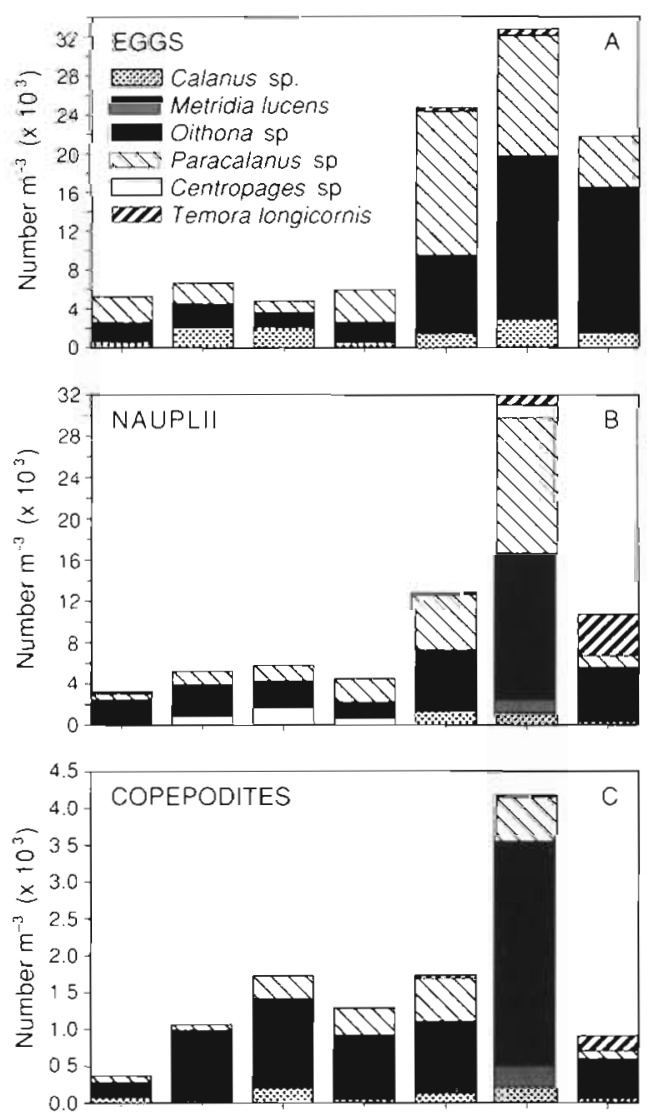

tion patterns were found for nauplii and copepodites (Figs. 5B, C). For adult copepods, this pattern was not evident (Fig. 5D); the number of adults peaked at Stn 18 but the abundance here was only $50 \%$ higher than that of the northern stations. The lowest abundance was observed at $\operatorname{Stn} 27$. The total copepod biomass (all stages) increased from about $2.5 \mathrm{mg} \mathrm{C} \mathrm{m}^{-3}$ at the northern stations to $8.8 \mathrm{mg} \mathrm{C} \mathrm{m}^{-3}$ at Stn 21 just south of the Dogger Bank (Fig, 5E).

The abundance of the most important other zoo-
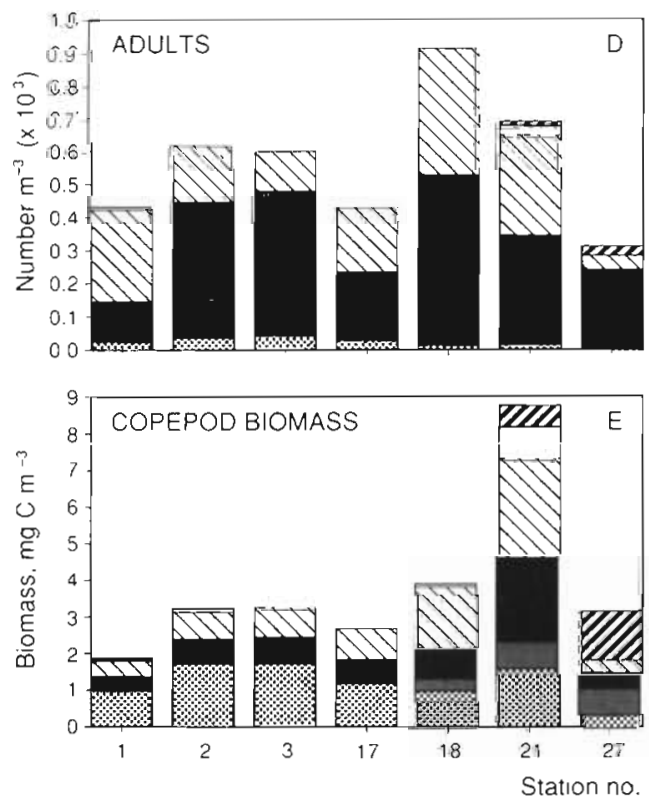

Fig. 5. (A to D) Abundance of copepod eggs, nauplii, copepodites, and adults (number $\times 10^{3} \mathrm{~m}^{-3}$ ), and $(E)$ biomass of the total copepod community ( $\mathrm{mg} \mathrm{C} \mathrm{m}{ }^{-3}$ ). Values were obtained from depth-integrated samples. Eggs of Calanus sp. and Metridia lucens are pooled (as Calanus sp.) and Paracalanus, Temora, Acartia eggs are shown together (as Temora). Biomasses of Paracalanus sp. and Centropages sp. include

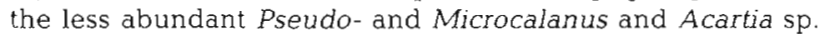
respectively 
plankters followed the trends seen for the younger copepod stages (Fig. 6). Since the microzooplankton samples contained very few organisms $(0$ to 3 ciliates $\left.1^{-1}\right)$, the ciliates were quantified in the samples for mesozooplankton. Results are included in Fig. 6. The ciliates were represented by the tintinnids Parafavella denticulata and Favella sp.

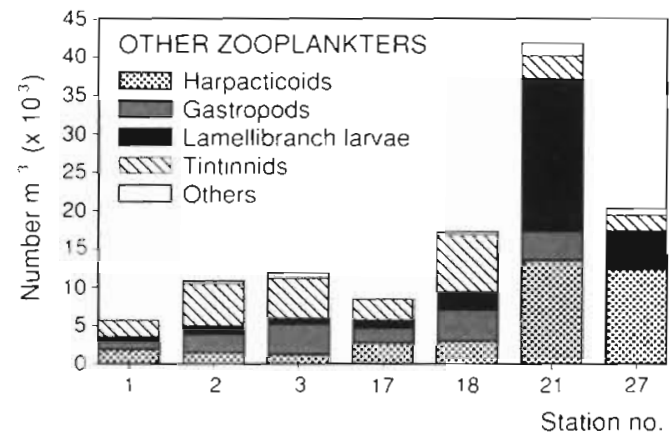

Fig. 6. Distribution of other zooplankters during the February/ March cruise

Determination of copepod egg production rates was carried out at 8 stations. Egg production was generally higher at stations south of $56^{\circ} \mathrm{N}(18,24$ and 27$)$ as compared to the northern stations. The egg production of the only species collected at all stations, Calanus finmarchius, is shown in Fig. 2F. Egg production rate peaked at the shallow Stn 24 in the same area where the highest chlorophyll a values were recorded (Fig. 2D). Egg production rate of the other species was generally lower $\left(<5\right.$ eggs female $\left.{ }^{-1} \mathrm{~d}^{-1}\right)$ than rates measured for Calanus (Table 4)

\section{May/June cruise}

The 21 stations visited on this cruise have been divided into 8 regions on the basis of hydrographic characteristics (S \%, $\mathrm{T}^{\circ} \mathrm{C}$ and nutrients). Data from these regions are summarized in Fig. 7 and Table 5. Generally, the abundance and biomass of bacteria and heterotrophic nanoflagellates were much higher at this time than during the early spring cruise. The chlorophyll a concentration was generally low $(0.17$ to $1.8 \mu \mathrm{g} \mathrm{I}^{-1}$; mean: $0.6 \mu \mathrm{gl}^{-1}$ ). Highest chlorophyll values were recorded in Region 2 in the Norwegian Coastal Current. Bacterial abundance and biomass were in the range 1.23 to $3.34 \times 10^{9} \mathrm{l}^{-1}$ (mean: $1.98 \times 10^{9} \mathrm{l}^{-1}$ ) and 13.3 to $53.8 \mu \mathrm{g} \mathrm{Cl}^{-1}$ (mean: $26 \mu \mathrm{g} \mathrm{Cl}^{-1}$ ), respectively. Rod-shaped bacteria constituted $53 \%$ (35 to $63 \%$ ) of the population. Abundance and biomass of heterotrophic nanoflagellates was 0.6 to $6.6 \times 10^{6} 1^{-1}$ (mean: $1.4 \times 10^{6} \mathrm{l}^{-1}$ ) and 0.7 to $20 \mu \mathrm{g} \mathrm{Cl}^{-1}$ (mean: $3.9 \mu \mathrm{g} \mathrm{Cl}^{-1}$ ), respectively. Their estimated clearance was within the range 3 to $40 \%$ (mean: $7.8 \%$ ) of the water column per day.



Fig. 7. Stations investigated during the May/June cruise. In the 8 regions the biomasses of algae, bacteria and heterotrophic flagellates are indicated; units are $\mathrm{mg} \mathrm{C} \mathrm{m}^{-3}$. (•) Station location

Table 4. Measurement of copepod egg production rate (egg female ${ }^{-1} \mathrm{~d}^{-1}$ ) during the February/March cruise

\begin{tabular}{|c|c|c|c|c|c|c|c|c|}
\hline \multirow[t]{2}{*}{ Species } & \multicolumn{8}{|c|}{ Station } \\
\hline & 1. & 2 & 3 & 14 & 17 & 18 & 21 & 27 \\
\hline Acartia spp. & 2.0 & 4.8 & & & & & & \\
\hline Calanus finmarchius & 2.7 & 6.8 & 6.5 & 4.8 & 1.3 & 10.9 & 17.6 & 11.9 \\
\hline Metridia lucens & & 3.4 & 0.3 & 2.0 & 2.0 & 2.0 & 2.5 & 1.0 \\
\hline Oitona $\mathrm{spp}$ & 1.9 & 0 & 0 & 0 & 0 & 1.9 & 2.8 & 0 \\
\hline Paracalanus parvus & 0 & 0 & 0.5 & 0.7 & 0.7 & 3.6 & 3.8 & 1.0 \\
\hline Pseudocalanus spp. & 1.0 & 0.3 & 1.0 & 1.0 & & 1.0 & 0 & \\
\hline Temora longicomis & 2.2 & & & & 2 & & & 5.3 \\
\hline
\end{tabular}


Table 5. Biomass and volume of bacteria and number, volume and calculated clearance of heterotrophic nanoflagellates during the May/June cruise

\begin{tabular}{|c|c|c|c|c|c|}
\hline \multirow{2}{*}{ Region } & \multicolumn{2}{|c|}{ Bacteria } & \multicolumn{3}{|c|}{ Heterotrophic flagellates } \\
\hline & $\begin{array}{l}\text { Number } \\
\left(\times 10^{9} 1^{-1}\right)\end{array}$ & $\begin{array}{l}\text { Volume } \\
\left(\mu \mathrm{m}^{3}\right)\end{array}$ & $\begin{array}{l}\text { Number } \\
\left(\times 10^{6} 1^{-1}\right)\end{array}$ & $\begin{array}{c}\text { Volume } \\
\left(\mu \mathrm{m}^{j}\right)\end{array}$ & $\begin{array}{l}\text { Clearance } \% \text { of } \\
\text { water column } \mathrm{d}^{-1}\end{array}$ \\
\hline 1 & 2.7 & 0.104 & 0.9 & 26 & 5.3 \\
\hline 2 & 1.85 & 0.103 & 6.6 & 25 & 40.0 \\
\hline 3 & 2.0 & 0.101 & 1.0 & 25 & 6.0 \\
\hline 4 & 2.3 & 0.138 & 1.1 & 23 & 6.0 \\
\hline 5 & 1.38 & 0.112 & 1.4 & 23 & 7.0 \\
\hline 6 & 2.2 & 0.123 & 1.1 & 26 & 6.0 \\
\hline 7 & 1.61 & 0.069 & 0.7 & 24 & 4.0 \\
\hline 8 & 1.24 & 0.091 & 1.3 & 31 & 10.0 \\
\hline
\end{tabular}

\section{DISCUSSION}

\section{Carbon flow budgets during the February/March cruise}

Carbon flow budgets for the different regions of the North Sea can be established on the basis of the February/March data. The values shown in Fig. 8 represent mean values for the upper $20 \mathrm{~m}$ of the water column, which roughly corresponds to the photic zone.

During this investigation, the copepod community was able to graze 1 to $4.5 \%$ (mean: $2.7 \%$ ) of the primary production at the northern stations where the spring bloom had not yet developed (Fig. 8A). At the northern edge (Stn 18) and south of the Dogger Bank (Stns 19 to 26) where the spring bloom was initiated, 1.2 and $1.1 \%$ of the primary production was grazed daily (Fig. $8 \mathrm{~B}, \mathrm{C}$ ) while only $0.4 \%$ of the declining phytoplankton bloom at Stn 27 was grazed by copepods (Fig. 8D). Thus, the percentage of primary production grazed at this time by copepods is about the same in the northern and southern parts of the North Sea. However, the calculated input to the benthos is at least 10 times larger, just south of the Dogger Bank, $1650 \mathrm{mg} \mathrm{C} \mathrm{m}^{-2} \mathrm{~d}^{-1}$ in contrast to $150 \mathrm{mg} \mathrm{C} \mathrm{m}^{-2} \mathrm{~d}^{-1}$ in the northern region (Fig. $8 \mathrm{~A}, \mathrm{C}$ ). It is important to remember that these calculations represent an instantaneous picture' and it is possible that a part of the senescing bloom may later be resuspended off the bottom and remineralized by bacteria and protozoa in the water column in the post-bloom period. The phytoplankton bloom had not yet developed in the northern North Sea during the present study. However, due to the large overwintering population of Calanus finmarchius in this region (Krause \& Thrams 1983) which mature several months before the spring bloom (Tande \& Hopkins 1981 and Table 4) and the higher temperature, we expect a large grazing impact on the bloom as shown by Williams \& Lindley (1980). This would result in an input of carbon to the benthos of about one third of that in the southern region, assuming the same primary production during the bloom and that about $33 \%$ (Kiørboe et al. 1985b) of the ingested carbon is channelled to the bottom as faeces.

Abundances of bacteria and heterotrophic nanoflagellates were low at all stations visited during the February/March cruise (Fig. 4; Table 2). Lowest values were found at the northern stations and may be related to the low rates of primary production. South of the Dogger Bank, where the spring bloom had begun, higher bacterial biomass and production were observed. Although bacterial biomass and production were higher in this region, their relative importance was lower than in the northern North Sea because of the high primary production south of the Bank ( $\mathrm{Ta}$ ble 6). In the southern bight of the North Sea, Lancelot \& Billen (1984) found a close coupling between hetero-

Table 6. Bacterioplankton biomass and production as percentage of phytoplankton biomass and production during the February/March cruise

\begin{tabular}{|ccccc|}
\hline & \multicolumn{5}{c|}{ Station } \\
& $1-17$ & $18^{-19}$ & $19-24$ & 27 \\
\hline $\mathrm{BB} \times 100 / \mathrm{PB}$ & 13 & 6 & 1 & 4 \\
$\mathrm{BP} \times 100 / \mathrm{PP}$ & 10 & 7 & 3 & 4 \\
\hline
\end{tabular}

trophic bacterial production and the development of the spring bloom (following a $10 \mathrm{~d}$ lag). Thus, the increased bacterial biomass and production in the Dogger Bank area after some days/weeks could be expected to initiate the trophic coupling to the heterotrophic nanoflagellates (Andersen \& Fenchel 1985).

The low number of ciliates present in the entire study area was probably due to the dominance of large diatoms and the low abundance of heterotrophic and autotrophic flagellates (Table $3 ;$ Fig. 3C). The only 


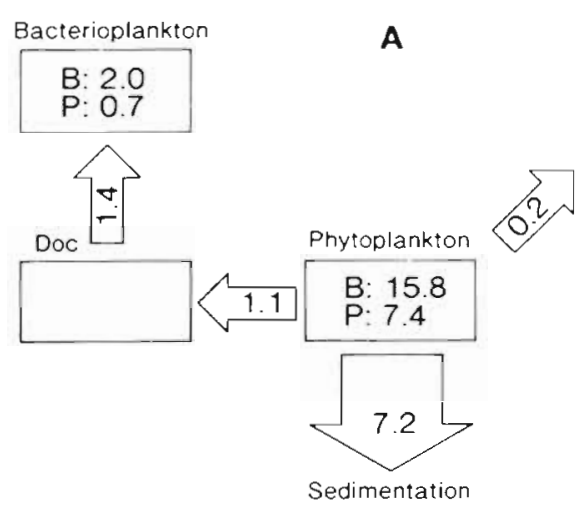

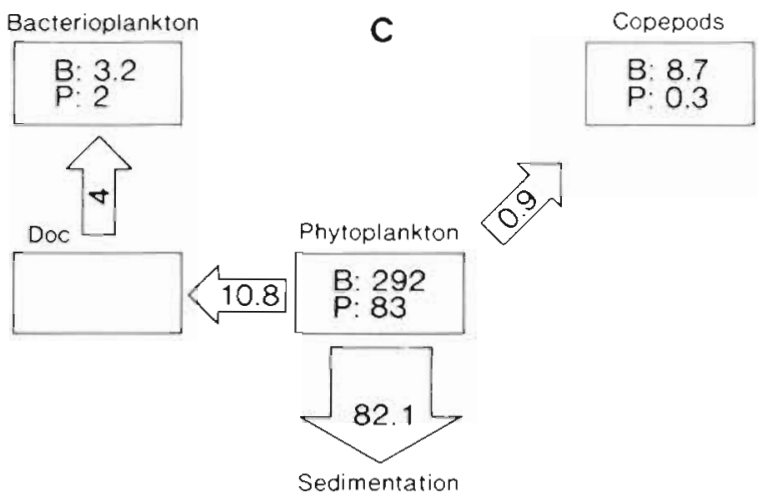
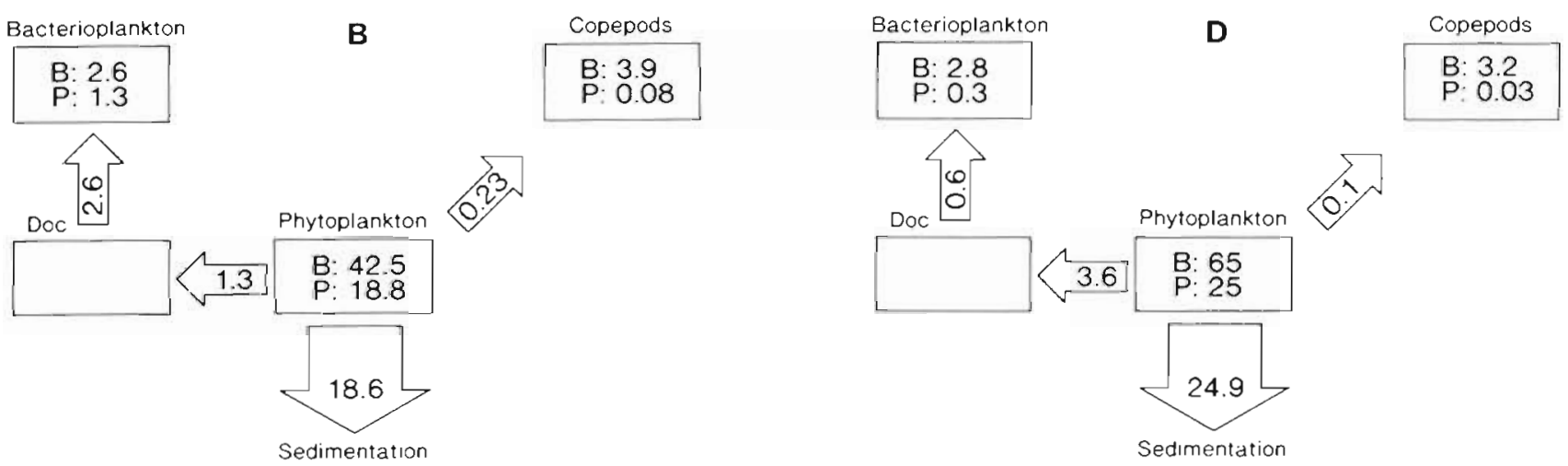

Fig. 8. Carbon flow budgets for the 4 regions investigated during the February/March cruise. (A) Deep northern stations (Stns 1 to $17)_{\text {; }}$ water depth $>100 \mathrm{~m}$, temperature ca $7^{\circ} \mathrm{C}$, chlorophyll $<1 \mu \mathrm{g} \mathrm{I} \mathrm{I}^{-1}$; phytoplankton dominated by Nitzschia longissima, Plagiogramma brockmanni and Detonula confervacea. (B) Border station (Stn 18); on the northern edge of the Dogger Bank, depth ca $40 \mathrm{~m}$, temperature ca $6^{\circ} \mathrm{C}$, chlorophyll ca $1 \mu \mathrm{g} \mathrm{I} \mathrm{I}^{-1}$; phytoplankton dominated by Chaetoceros decipiens, Melosira sulcata and Rhizoselenia shrubsolei. (C) Just south of the Dogger Bank (Stns 19 to 26); shallow water $<30 \mathrm{~m}$, temperature ca $5^{\circ} \mathrm{C}$, chlorophyll $>5 \mu \mathrm{g}^{-1}$; phytoplankton dominated by Rhizoselenia shrubsolei and $R$. stolterfothii. (D) Str 27 ; water depth ca $40 \mathrm{~m}$, with lower salinity than for the more westerly North Sea stations, chlorophyll ca $1.5 \mu \mathrm{g} \mathrm{l}^{-1}$; phytoplankton population characterized by a declining Rhizosolenia shrubsolei bloom. Units for biomass (B) and production (P) are $\mathrm{mg} \mathrm{C} \mathrm{m}{ }^{-3}$ and $\mathrm{mg} \mathrm{C} \mathrm{m}^{-3} \mathrm{~d}^{-1}$ respectively Doc: dissolved organic carbon

species present were large tintinnids that are able to graze relatively large algal cells. These observations indicate low activity and a relatively unimportant role of the microbial loop in the carbon turnover before and during the spring bloom in the North Sea. Investigations in coastal waters have shown that protozooplankton peak 2 to 3 wk after the spring bloom (Smetacek 1981, Stegermann \& Peinert 1984) and a similar pattern following a diatom bloom has been shown in the Sea of Japan (Sorokin 1977).

\section{May/June cruise}

During the second cruise, the water had stratified and the phytoplankton was dominated by autotrophic nanoflagellates. At this time, the biomass of bacteria and heterotrophic nanoflagellates had built up and the heterotrophic microbial biomass constituted a much larger fraction of the pelagic carbon pool than during the spring cruise (Fig. 7; Table 5). Abundances of bacteria and heterotrophic nanoflagellates were within the ranges reported from other areas $\left(0.5\right.$ to $5 \times 10^{9}$ and 0.5 to $5 \times 10^{6}$ cells $1^{-1}$ respectively) e.g. Sargasso and Caribbean Seas (Sieburth \& Davis 1982), English Channel and Benguela upwelling region of South Africa (Linley et al. 1983), North Bering/Chukchi Seas (Andersen 1988), upwelling off central Chile (McManus \& Peterson 1988). Unfortunately, this cruise did not include stations on the Dogger Bank. Due to the vertical mixing occurring in this region, one might expect a dominance of larger algal species and a relative smaller biomass of heterotrophic microbes compared with the northern stratified regions. The increase 
Table 7. Bacterioplankton biomass as percentage of phytoplankton biomass during the May/June cruise

\begin{tabular}{|ccccccccc|}
\hline Region & 1 & 2 & 3 & 4 & 5 & 6 & 7 & 8 \\
\hline$\%$ & 50 & 26 & 85 & 137 & 120 & 161 & 62 & 67 \\
\hline
\end{tabular}

in the ratio of bacteria to phytoplankton carbon on the May/June cruise (Fig. 7; Table 7) illustrates a seasonal change in the importance of the microbial loop from the spring bloom to a stratified summer situation in the North Sea.

Comparisons of bacterial and phytoplankton biomass are encumbered with large variation due to the span in the conversion factors from volume to carbon and variations in determination of cell volume (reviewed by Bjornsen \& Riemann 1988). However, even when using a relatively low conversion factor, the bacterial biomass is higher than the phytoplankton biomass in the central regions (Fig. 7; Table 7). This high biomass might be due to DOM released by senescent diatoms in the days/ weeks prior to the cruise, taken up and accumulated in the bacterioplankton.

Our findings suggest that the microbial loop plays a modest role during the spring bloom but becomes important later when the phytoplankton is dominated by small forms. This, in part, reflects the fact that large diatoms are unsuitable as food for protozoa. The size structure of the phytoplankton may also determine the relative amount of primary production which is released as dissolved organics. Bjørnsen (1988) suggest that algal exudation of DOM is passive leakage through the cell membrane. A pelagic community dominated by small algae will therefore leak a larger portion of primary production to the microbial loop than a community dominated by large algae. Andersen (1988) found a similar pattern in the North Bering Sea: that the relative importance of the microbial loop was substantial at stations dominated by pico- and nanophytoplankton but modest where the plankton was dominated by diatoms.

\section{Copepod grazing impact on the spring bloom}

In temperate coastal waters, copepods only consume a small fraction of the spring bloom primary production (e.g. Nicolajsen et al. 1983, Stearns et al. 1987, Falkowski et al. 1988, Smith \& Lane 1988). The reason for this is the small overwintering population of neritic copepods, their adaptation to higher temperatures (Kiorboe et al. 1982) and the resulting slow numerical response relative to the rapid growth of diatoms. For the Kattegat-Skagerrak area, Tiselius (1988) concluded that the presence of Calanus finmarchius was essential for a significant grazing impact. At stations dominated by smaller neritic species, grazing impact by copepods was neglible.

In general, a high grazing impact during the spring bloom seems to be associated with the presence of large oceanic species such as Calanus finmarchius. These species form large overwintering populations which can efficently exploit the spring bloom (Krause \& Thrams 1983).

In contrast to the former comprehension of the fate of the carbon entering the North Sea food chain. (Steele 1974), this investigation illustrates that the grazing impact of the copepods during the spring bloom in the southern North Sea is of minor importance. The role of the microbial loop in the turnover of carbon at this time of the year was also negligible. Thus, the major part of the primary production occurring during the spring bloom must be transferred directly to the benthos.

The present investigation stresses the need for further study of carbon cycling in the North Sea, especially in the Dogger Bank area. Since this Bank represents a 'stable' oceanographic discontinuity, high rates of primary production dominated by large algae can be expected to take place in the relative turbulent nutrient-rich waters during a large part of the year (Legendre et al. 1986).

Understanding the fate of this production is essential to an increased understanding of the ecology of the North Sea and the proper management of the commercial exploitation of the resources in this region.

Acknowledgements. We are grateful to Tom Fenchel, Thomas Kiørboe and Bo Riemann for valuble discussions and criticism of the manuscript. We are indebted to Alice Christoffersen, Stina Bilstrup, Grethe Germod, Lisbeth Jensen and Bo Skaarup for excellent technical assistance and the crew of RV 'Dana' for help with sampling. This investigation was supported in part by grant No. 11-6480 from the Danish Natural Science Research Council.

\section{LITERATURE CITED}

Andersen, P. (1988). The quantitative importance of the 'microbial loop' in the marine pelagic: a case study from the North Bering/Chuckchi Seas. Arch. Hydrobiol., Beih. Ergebn. Limnol. 31: 243-251

Andersen, P., Fenchel, T. (1985). Bacterivory by microheterotrophic flagellates in seawater samples. Limnol. Oceanogr. 30: 198-202

Andersen, P., Sørensen, H. M. (1986). Population dynamics and trophic coupling in pelagic microorganisms in eutrophic sea water. Mar. Ecol. Prog. Ser. 33: 99-109

Antia, N. J., McAllister, C. D., Parsons, T. R., Stephens, R., Strickland, J. D. H. (1963). Further measurement of primary production in coastal sea water using a large volume plastic sphere. Limnol. Oceanogr. 6: 237-258

Azam, F., Fenchel, T., Field, J. G., Grey, J. S., Meyer-Reil, L. 
A., Thingstad, F. (1983). The ecological role of watercolumn microbes in the sea. Mar. Ecol. Prog. Ser. 10: $257-263$

Baars, M. A., Fransz, H. G. (1984). Grazing pressure of copepods on the phytoplankton stock of the central North Sea. Neth. J. Sea Res. 18: 120-142

Berggreen, U., Hansen, B., Kiorboe, T (1988). Food size spectra, ingestion and growth of the copepod Acartia tonsa: implications for the determination of copepod production. Mar. Biol. 99: 341-352

Bjørnsen, P. K. (1988). Phytoplankton release of organic matter: why do healthy cells do it? Limnol. Oceanogr. 33 $151-154$

Bjørnsen, P. K., Riemann, B. (1988). Towards a quantitative stage in the study of microbial processes in pelagic carbon flows. Arch. Hydrobiol., Beih. Ergebn. Limnol. 31: 185-193

Bjørnsen, P. K., Riemann, B., Horsted, S. J., Nielsen, T G., Pock-Steen, J. (1988). Trophic interactions between heterotrophic nanoflagellates and bacterioplankton in manipulated seawater enclosures. Limnol. Oceanogr. 33 (3) $409-420$

Bottrel, H. H., Robins, D. B. (1984). Seasonal variation in length, dry weight, carbon and nitrogen of Calanus helgolandicus from the Celtic Sea. Mar Ecol. Prog. Ser. 14 259-268

Cohen, R. E., Lough, R. G. (1981). Length-weight relationship for several copepods dominant in the Georges Bank-Gult of Maine area. J. Northw. Atl. Fish. Sci. 2: 47-52

Cole, J. J. (1982). Interaction between bacteria and algae in aquatic ecosystems. Ann. Rev. Ecol. Syst. 13: 291-314

Cushing, D. H. (1959). On the nature of production in the sea Fishery Invest. Lond. Ser. 2, 22 (6): 1-40

Dagg, M. J., Vidal, J., Whiteledge, T E., Iverson, R. L., Goering, J. J. (1982). The feeding, respiration, and excretion of zooplankton in the Bering Sea during a spring bloom. Deep Sea Res. 29: 45-63

Evans, G. T., Parslow, J. S. (1985). A model of annual plankton cycles. Biol. Oceanogr. 3: 327-347

Falkowski, P. G., Flagg, C. N., Rowe, G. T., Smith, S. L., Whitledge, T E., Wirick, C. D. (1988). The fate of a spring phytoplankton bloom: export or oxidation. Cont. Shelf Res. 8: $457-484$

Fenchel, T (1982). Ecology of heterotrophic microflagellates. IV. Quantitative occurrence and importance as bacterial consumers. Mar. Ecol. Prog. Ser 9: 35-42

Fenchel, T (1986). Protozoan filter feeding. Prog. Protistol. 1 63-113

Fuhrmann, J., Azam, F. (1980). Bacterioplankton secondary production estimates for coastal waters off British Columbia, Antarctica and California. Appl. environ. Microbiol 39: $1085-1095$

Grashoff, K. (1976). Methods of seawater analysis. Weinheim, New York

Hobbie, J. E., Daley, R, J., Jaspers, S. (1977). Use of nucleopore filters for counting bacteria by epifluorescence. Appl. environ. Microbiol. 33: 1225-1228

Joris, C., Billen, G., Lancelot, C., Daro, M. H., Mommaerts, J. P., Bertels, A., Bossicart, M., NIjs, J., Hecq, J. H. (1982). A budget of carbon cycling in the Belgian coastal zone: relative roles of zooplankton, bacterioplankton and benthos in the utilization of prmary production. Neth. J. Sea Res. 16: 260-275

Klein Breteler, W. M. C., Fransz, H. G., Gonzalez, S. R. (1982). Growth and development of four calanoid copepod species under experimental and natural conditions. Neth. J. Sea Res. 16: 195-207

Kiørboe, T., Møhlenberg, F., Nicolajsen, H. (1982). Ingestion rate and gut clearance in the planktonic copepod Centropages hamatus (Lilljeborg) in relation to food and temperature. Ophelia 21.181-194

Kiørboe, T., Mohlenberg, F., Riisgaard, H. U. (1985a). In situ feeding rates of planktonic copepods: a comparison of four methods. J. exp. mar. Biol. Ecol. 88: 67-81

Kiørboe, T., Mohlenberg, F., Hamburger, K. (1985b) Bioenergetics of the planktonic copepod Acartia tonsa: relation between feeding, egg production and respiration and composition of specific dynamic action. Mar. Ecol. Prog. Ser. 26: 85-97

Krause, M., Thrams, J. (1983). Zooplankton dynamics during FLEX 76. In: Sundermann, J., Lentz, W. (eds.) North Sea dynamics. Springer-Verlag, Berlin, p. 632-661

Larsson, U., Hagström, А. (1982). Fractionated phytoplankton primary production, exudate release and bacterial production in a Baltic eutrophicated gradient. Mar. Biol. 67: 57-70

Lancelot, C., Billen, G. (1984). Activity of heterotrophic bacteria and its coupling to primary production during the spring bloom in the southern bight of the North Sea Limnol. Oceanogr. 29: 721-730

Legendre, L., Demers, S., Lefaivre, D. (1986). Biological production at marine ergoclines. In: Nihoul, J. C. J. (ed.) Marine interfaces ecohydrodynamics. Elsevier, Amsterdann, p. 191-207

Linley, E. A. S., Newell, R. C., Lucas, M. I. (1983). Quantitative relationships between phytoplankton, bacteria and heterotrophic microflagellates in shelf waters. Mar. Ecol. Prog. Ser. 12: 77-89

McManus, G. B., Peterson, W. T. (1988). Bacterioplankton production in the nearshore zone during upwelling off central Chile. Mar. Ecol. Prog. Ser. 43: 11-17

Nicolajsen, H., Mohlenberg, F., Kiorboe, T (1983). Algal grazing rate by the planktonic copepod Centropages hamatus and Pseudocalanus sp.: diumal and seasonal variation during the spring phytoplankton bloom in the Øresund. Ophelia 22: 15-31

Peterson, W. T. (1988). Rates of egg production by the copepod Calanus marshallae in the laboratory and in the sea off Oregon, USA. Mar. Ecol. Prog. Ser. 47: 229-237

Richardson, K. (1985). Plankton distribution and activity in the North Sea/Skagerrak-Kattegat frontal area in April 1984. Mar. Ecol. Prog. Ser 26: 233-244

Richardson, K., Heath, M. R., Petersen, S. M. (1986). Studies of a larval herring (Clupea harengus L.) patch in the Buchan area. III. Phytoplankton distribution and primary production in relation to hydrographic teatures. Dana 6: 25-35

Riemann, B., Bjornsen, P. K., Newell, S. Fallon, R. (1987). Calculation of cell production of coastal marine bacteria based on measured incorporation of $\left[{ }^{3} \mathrm{H}\right]$ Thymidine. Limnol. Oceanogr. 32 (2): 471-476

Roff, J. C., Middlebrook, K, Evans, F. (1988). Long-term variability in North Sea zooplankton off the Northumberland coast: productivity of small copepods and analysis of trophic interactions. J. mar biol. Ass. U.K 68: 143-164

Sherr, E. B., Sherr, B. F., Paffenhöfer, G.-A. (1986). Phagotrophic protozoa as a food for metazoans: a missing trophic link in marine pelagic food webs. Mar. microb. Food Webs 1 (2): 61-80

Sieburth, J. McN. Davis, P. G. (1982). The role of heterotrophic nanoplankton in the grazing and nuturing of planktonic bacterla in the Sargasso and Caribbean Seas. Ann. Inst. océanogr, Paris 58: 285-296

Smetacek, V (1981). The annual cycle of protozooplankton in the Kiel Bight. Mar Biol. 63: 1-11

Smetacek, V (1984). The food supply to the benthos. In Fasham, M. J. (ed.) Flows of energy and materials in 
marine ecosystems: theory and practice. Plenum Press, New York, p. 517-548

Smith, S. L., Lane, P. V. Z. (1988). Grazing of the spring diatom bloom in the New York Bight by the calanoid copepods Calanus finmarchius, Metridia lucens and Centropages typicus. Cont. Shelf Res. 8: 485-509

Sorokin, Yu. I. (1977). The heterotrophic phase of plankton succession in the Japan Sea. Mar. Biol. 41: 107-117

Stearns, D. E., Litaker, W., Rosenberg, G. (1987). Impacts of zooplankton grazing and excretion on short-interval fluctuations in chlorophyll $a$ and nitrogen concentration in a well-mixed estuary. Estuar. coast. Shelf Sci. 24: 305-325

Steele, J. H. (1974). The structure of marine ecosystems. Harvard University press, Cambridge

Stegermann, P., Peinert, R. (1984). Interrelationship between herbirovous zooplankton and phytoplankton and their effect on production and sedimentation of organic matter in Kiel Bight. Limnologica (Berl.) 15: 487-495

This article was presented by Dr T. Kiørboe, Charlottenlund, Denmark
Tande, K. S., Hopkins, C. C. E. (1981). Ecological investigation of the zooplankton community of Balsfjorden, northern Norway. The genital system in copepodite stage IV and $V$ Calanus finmarchius. The role of gonad development in the overwintering strategy. Mar Biol. 63: $159-164$

Tiselius, P. (1988). Effects of diurnal feeding rythms, species composition and vertical migration on the grazing impact of calanoid copepods in the Skagerrak and Kattegat. Ophelia 28: 215-230

Watson, S. W., Novitsky, T. J., Quinby, H. L., Valois, F. W. (1977). Determination of bacterial number and biomass in the marine environment. Appl. environ. Microbiol. 53: 940-946

Williams, R., Lindley, J. A. (1980). Plankton on the Fladen Ground during FLEX 76. III. Vertical distribution, population dynamics and production of Calanus finmarchius (Crustacea: Copepoda). Mar. Biol. 60:47-56

Manuscript first received: January 26, 1989

Revised version accepted: May 22, 1989 